\title{
Yield Analysis and Adaptation for Bacillus Thuringiensis (BT) and Non- Bacillus Thuringiensis (BT) Cotton Varieties in the Kingdom of Eswatini
}

\author{
Author by Daniel Khumalo \\ PhD, Management, Texila University \\ E-mail:dmkhumalo66@gmail.com
}

\begin{abstract}
Cotton in Eswatini contributes $2.1 \%$ of the country's Gross Domestic Product owing to low cotton yield due to high pest pressure. Eswatini farmers grow Alba QM 301 a conventional non Bt variety which is affected by bollworm. Cotton is no longer profitable and farmers are quitting the industry, yet it is the only source of livelihood in drought prone areas of Eswatini. Countries like India and South Africa have replaced conventional cotton with high yielding Bt or genetically modified cotton. The study analyses yield and adaptation of Bt cotton under rain fed condition. Bt cotton hybrid was evaluated under field condition for adaptation and yield performance in 2016 and 2017 season. Two Bt cotton varieties JKCH 1947 Bt and JKCH 1050 Bt were tested against the local variety Alba Plus QM 301 and JKC 724 both Non Bt (NBt). JKCH 1947 recorded significantly higher seed cotton yield per ha of $3070 \mathrm{~kg} / \mathrm{ha}$ on the first year. It was closely followed by JKCH 1050 with a yields of $2955 \mathrm{~kg} / \mathrm{ha}$. The number of boll per plant was also significant higher compared the control. Alba Plus QM 301 and JKC 724 both Non Bt (NBt) recorded the lower yields of 2066 and $821 \mathrm{~kg} / \mathrm{ha}$ respectively, under the same condition with less number of bolls per plant. Similar observations were recorded on the second year, $\mathrm{JKCH} 1947$ and $\mathrm{JKCH} 1050$ recording $1765 \mathrm{~kg} / \mathrm{ha}$ and $1865 \mathrm{~kg} / \mathrm{ha}$ respectively. A similar trend was observed on the number of bolls per plant, higher number of bolls were recorded in JKCH $1050 \mathrm{Bt}$ followed by JKCH 1947 Bt. Alba Plus QM 301 NBt and JKC 724 NBt recorded fewer boll in both years. All varieties showed good adaptability to local environment with good plant stand.
\end{abstract}

Keywords: Bt cotton, rain fed conditions, seed cotton.

\section{Introduction}

This paper is about introducing genetically modified cotton in the Kingdom of Eswatini. Discussions in the paper are guided by management processes of introducing a new product or new technology in a market. In the Kingdom of Eswatini, agriculture plays a major role in the economy; it's a major source of food, and also employs more than $60 \%$ of the country's population (ISAAA, 2014; Thomson, 2012). Eswatini's agriculture is mainly dependent on sugar cane, cotton and forestry. Cotton is the second biggest cash crop after sugarcane in Eswatini. It is an important cash crop for most Swazis who live on drought prone areas and smallholder farmers who are reliant on the crop for their livelihood (Central Bank of Swaziland, 2013). Eswatini farmers are still entirely reliant on conventional hybrid cotton seeds. Hybrid cotton seeds have long been used in the industry as the sole means for cotton production.

Genetically modified cotton is a variety of cotton that has been modified through a biotechnological process in order to achieve a higher yield. Bollworm resistant, Bacillus Thuringiensis (BT) cotton is the most popular genetically modified cotton seed used throughout the world. Genetically modified cotton was first introduced in the early 1990s and has since been adopted by major cotton producing countries such as the USA, India, China and South Africa (James, 2011). The genetically modified cotton seeds are engineered via a biotechnological process to reproduce the soil bacterium Bacillus Thuringiensis in a crystal form in order to exterminate certain types of insects and pests which damage the cotton crop and reduce farmer's yields (Craig et al., 2008). The new genetically modified seed has outstripped its traditional hybrid counterparts in terms of yield (Brookes \& Barfoot, 2013).

In Eswatini, the cotton industry is currently facing a decline in production and this has affected the textile industries which relied on Eswatini cotton as their main source of inputs. Most textile industries have closed due to the shortage of cotton. The few textile factories that are operational survive through importing cotton supplement locally depressed supplies for the daily operations. The government of 
Eswatini has to revive the cotton industry by introducing a new product in the market. The purpose of this paper is to analyse yield and adaptability of genetically modified cotton in Eswatini. The paper will compare two Bt cotton varieties against the locally grown conventional cotton variety by evaluating the agronomic characteristics of the varieties under condition of the in the Kingdom of Eswatini.

The cotton industry in Eswatini is currently facing many challenges. The country's largest cotton ginnery which is under the stewardship of the Swaziland Cotton Board (SCB) and located at Big Bend, has a capacity to handle 25000 metric tons of cotton. Currently, a mere $10 \%$ of the ginnery's capacity is being utilised owing to unavailability of inputs and decreased cotton production, among other reasons (Mavuso, 2014). The cotton industry is solely dependent on conventional hybrid cotton seeds. This product has been used by all cotton farmers for the past two decades (Cotton Board, 2014). However, the hybrid cotton seed has reached their decline phase and this is characterised by a rapid decrease in the yield of this product. The decrease in cotton production threatens the 90 ginnery employees' jobs at the Big Bend ginnery (Cotton Board, 2014).

Hybrid cotton that is currently grown by Eswatini farmers is no longer producing high yield as it used to do in the past years. The product has reached a decline phase which is characterized by high production cost, low yields, and heavy pesticides application requirements. From a management point of view a product in decline phase needs to be phased out and replaced because it will be fool hardy to rejuvenate the product (Kotler, 2012). Cotton acreage has drastically been reduced from 20,000 hectares to merely 3000 hectares (Cotton Board, 2013). Correspondingly, the number of cotton farmers in Eswatini has also decreased from 9000 to 3000 in the past 6 years (Cotton Board, 2013). The sector has a potential capacity to create employment directly and indirectly through the textile industry, ginning, spinning, and weaving of fabric respectively, has gone down. This has been aggravated by labour migration from rural areas to the cities (Thomson, 2012). The country has to find strategies of filling the demand gaps created by dwindling cotton production over the years and cheaper technology to continue producing enough cotton to meet increasing demand. Opportunities that are not utilised when they arise will always be taken up by one's competitors (Bryman, et. al. 2014). It is the researchers' conviction that the introduction of genetically modified cotton seed is one of the viable options to tackle the cotton industry's prevailing challenges. There is an urgent need to test the Genetically modified (Bt) technology under local condition and adopt genetically modified $(\mathrm{Bt})$ cotton technology to replace hybrid cotton seed.

In an effort to address the problem in the cotton industry of Eswatini it was essential to conduct agronomic trials of genetically modified $(\mathrm{Bt})$ cotton and test its adaptability under Eswatini soil and weather conditions. This study aimed analyzing yields and the agronomic traits of two Bt cotton hybrids, JKCH 1947 Bt and JKCH 1050 Bt against a popular control variety Alba Plus QM 301(non Bt) NBt and an inbred JKC $724 \mathrm{NBt}$ for yield potential and adaptability. The field experiment was conducted over 2 year, 2016 and 2017 season.

\section{Materials and methods}

Field experiment was conducted at two years on the same site in Eswatini during 2016 and 2017 planting season. The trials focused on agronomic and yield performance of two Bt cotton hybrids (JKCH $1947 \mathrm{Bt}$ and JKCH $1050 \mathrm{Bt}$ ), inbred (JKC 724 Non Bt) developed and owned by JK Agri Genetics Limited and the control was a locally grow conventional variety (Alba Plus QM 301 Non Bt). The Lowveld Experimental Station (LES) is located in the Lowveld region $\left(26^{\circ} 57.95 \mathrm{~S}, 31^{\circ} 31.52 \mathrm{E}\right.$; $89 \mathrm{~m}$ asl), with mean temperatures ranging between 26.4 to $30.5^{\circ} \mathrm{C}$ and annual rainfall of $450 \mathrm{~mm}$. The soils are M-series, which are sandy loam, well drained and fertile (Murdoch, 1968). The experiment used a randomized complete block design (RCBD) with six replications. Gross plot size of experiment was 4 rows of 6 metres length planted at an inter-row spacing of $90 \mathrm{~cm}$ and $25 \mathrm{~cm}$ between plants. Whereas, the net plot constituted of 2 middle rows with each row having 20 plants thus a total of 40 plants for the net plot.

Observations were recorded on six randomly selected plants from each variety per replication for the characters viz., plant height (cm), no. of lateral branches, no. of lateral branhes ( $\geq 4$ bolls), days to 50\% flowering, no. of damaged bolls, no. of bolls/plant, damaged bolls (\%),50 bolls dry weight (g), ginning out turn $(\%)$ and cotton yield $(\mathrm{Kg} / \mathrm{Ha})$. Out of all the bolls per plant, fifty bolls were randomly selected 
and weighed using a digital balance. Thereafter, the seed cotton yield per plot was estimated after picking the cotton from the whole plot and adding the weight of the collected bolls. The values were up scale from $\mathrm{kg} / \mathrm{plot}$ to $\mathrm{kg} / \mathrm{ha}$ for each cotton strain and replication. Field management was done general agriculture practice in the cotton industry of Eswatini. Multiple foliar sprays were applied on control variety Alba Plus QM $301 \mathrm{NBt}$ and inbred JKC $724 \mathrm{NBt}$ to manage cotton bollworm infestation. No foliar sprays were applied on Bt cotton hybrids.

\section{Statistical analysis}

All data were expressed as mean with standard deviation. Agronomic and yield traits data from the cotton varieties were pooled and analysed using one way ANOVA. Analysis of variance was performed by using the ANOVA procedure of the SAS software (version 9.3 for windows). Significant differences between varieties agronomic and yield traits means were determined by Fischer's Least Significant Difference Test at the level of $\mathrm{p} \leq 0.05$.

\section{Results and discussion}

Table 1. Year 1 agronomic traits of Bt and Non-Bt cotton results

\begin{tabular}{|l|l|l|l|l|l|l|l|}
\hline $\begin{array}{l}\text { Cotton } \\
\text { Variety/Hybrid }\end{array}$ & $\begin{array}{l}\text { Plant } \\
\text { Height } \\
(\mathrm{cm})\end{array}$ & $\begin{array}{l}\text { No. of } \\
\text { Lateral } \\
\text { Branches }\end{array}$ & $\begin{array}{l}\text { No. of } \\
\text { lateral } \\
\text { Branhes } \\
(\geq 4 \\
\text { bolls })\end{array}$ & $\begin{array}{l}\text { Days to } \\
50 \% \\
\text { Flowerin } \\
\mathrm{g}\end{array}$ & $\begin{array}{l}\text { No. of } \\
\text { Damage } \\
\text { d Bolls }\end{array}$ & $\begin{array}{l}\text { No. of } \\
\text { bolls/plant }\end{array}$ & $\begin{array}{l}\text { Damaged } \\
\text { Bolls (\%) }\end{array}$ \\
\hline $\begin{array}{l}\text { Alba Plus QM } \\
\text { 301 NBt }\end{array}$ & $83.4 \mathrm{a}^{1}$ & $9.5 \mathrm{a}$ & $2.5 \mathrm{~b}$ & $106.5 \mathrm{a}$ & $20.5 \mathrm{a}$ & $58.8 \mathrm{~b}$ & 35.6 \\
\hline JKC 724 NBt & $48.1 \mathrm{~b}$ & $7.7 \mathrm{~b}$ & $3.0 \mathrm{ab}$ & $110.5 \mathrm{a}$ & $16.2 \mathrm{a}$ & $56.2 \mathrm{~b}$ & 29.0 \\
\hline JKCH 1947 Bt & $87.7 \mathrm{a}$ & $9.4 \mathrm{a}$ & $3.8 \mathrm{ab}$ & $84.8 \mathrm{~b}$ & $6.7 \mathrm{~b}$ & $92.0 \mathrm{a}$ & 7.6 \\
\hline JKCH 1050 Bt & $78.0 \mathrm{a}$ & $9.8 \mathrm{a}$ & $4.2 \mathrm{a}$ & $86.3 \mathrm{~b}$ & $6.1 \mathrm{~b}$ & $90.2 \mathrm{a}$ & 6.6 \\
\hline
\end{tabular}

${ }^{1}$ Means with the same letters within the same columns are non-significant with Fischer's Least Significant Differences (LSD) test

Table 2. Year 1 yield components of Bt and Non-Bt cotton results

\begin{tabular}{|l|l|l|l|}
\hline Cotton Variety/Hybrid & 50 Bolls Dry Weight (g) & Ginning Out Turn (\%) & Cotton Yield (Kg/Ha) \\
\hline Alba Plus QM 301 NBt & $283.3 \mathrm{a}^{1}$ & $44.7 \mathrm{a}$ & $2066 \mathrm{~b}$ \\
\hline JKC 724 NBt & $207.2 \mathrm{~b}$ & $40.8 \mathrm{c}$ & $1173 \mathrm{~b}$ \\
\hline JKCH 1947 Bt & $311.5 \mathrm{a}$ & $43.1 \mathrm{~b}$ & $3070 \mathrm{a}$ \\
\hline JKCH 1050 Bt & $294.7 \mathrm{a}$ & $43.3 \mathrm{~b}$ & $2955 \mathrm{a}$ \\
\hline
\end{tabular}

${ }^{1}$ Means with the same letters within the same columns are non-significant with Fischer's Least Significant Differences (LSD) test 
DOI: $10.21522 /$ TIJAR.2014.SE.19.01.Art008

ISSN: $2520-3088$

Table 3. year 2 Agronomic traits of Bt and Non-Bt cotton results

\begin{tabular}{|l|l|l|l|l|l|l|l|}
\hline $\begin{array}{l}\text { Cotton } \\
\text { Variety/Hy } \\
\text { brid }\end{array}$ & $\begin{array}{l}\text { Plant } \\
\text { Height } \\
(\mathrm{cm})\end{array}$ & $\begin{array}{l}\text { No. of } \\
\text { Lateral } \\
\text { Branches }\end{array}$ & $\begin{array}{l}\text { No. of lateral } \\
\text { Branhes }(\geq 4 \\
\text { bolls })\end{array}$ & $\begin{array}{l}\text { Days to } \\
50 \% \\
\text { Flowering }\end{array}$ & $\begin{array}{l}\text { No. of } \\
\text { Damaged } \\
\text { Bolls }\end{array}$ & $\begin{array}{l}\text { No. of } \\
\text { Bolls/P1 } \\
\text { ant }\end{array}$ & $\begin{array}{l}\text { Da } \\
\text { mag } \\
\text { ed } \\
\text { Boll } \\
\text { s } \\
(\%)\end{array}$ \\
\hline $\begin{array}{l}\text { Alba Plus } \\
\text { QM } 301 \\
\text { NBt }\end{array}$ & $131.0 a^{1}$ & $12.52 \mathrm{a}$ & $2.56 \mathrm{c}$ & $158.6 \mathrm{~b}$ & $1.0 \mathrm{a}$ & $41.2 \mathrm{~b}$ & 2.4 \\
\hline $\begin{array}{l}\mathrm{JKC} 724 \\
\mathrm{NBt}\end{array}$ & $89.0 \mathrm{~b}$ & $11.03 \mathrm{a}$ & $2.36 \mathrm{c}$ & $165 . \mathrm{a}$ & $1.2 \mathrm{a}$ & $37.3 \mathrm{~b}$ & 2.7 \\
\hline $\begin{array}{l}\mathrm{JKCH} \\
1947 \mathrm{Bt}\end{array}$ & $148.0 \mathrm{a}$ & $12.58 \mathrm{a}$ & $3.67 \mathrm{~b}$ & $101.5 \mathrm{c}$ & $0.3 \mathrm{a}$ & $65.5 \mathrm{a}$ & 0.5 \\
\hline $\begin{array}{l}\mathrm{JKCH} \\
1050 \mathrm{Bt}\end{array}$ & $131.0 \mathrm{a}$ & $12.92 \mathrm{a}$ & $5.39 \mathrm{a}$ & $106.1 \mathrm{c}$ & $0.5 \mathrm{a}$ & $67.2 \mathrm{a}$ & 0.7 \\
\hline
\end{tabular}

${ }^{1}$ Means with the same letters within the same columns are non-significant with Fischer's Least Significant Differences (LSD) test

Table 4. Year 2 yield components of Bt and Non-Bt cotton results

\begin{tabular}{|l|l|l|l|}
\hline Cotton Variety/Hybrid & 50 Bolls Dry Weight $(\mathrm{g}))$ & Ginning Out Turn \% & Cotton Yield (Kg/Ha) \\
\hline Alba Plus QM 301 NBt & $220.3 \mathrm{a}^{1}$ & $45.7 \mathrm{ab}$ & $1337 \mathrm{~b}$ \\
\hline JKC 724 NBt & $172.2 \mathrm{~b}$ & $44.0 \mathrm{~b}$ & $821 \mathrm{c}$ \\
\hline JKCH 1947 Bt & $226.8 \mathrm{a}$ & $46.3 \mathrm{a}$ & $1765 \mathrm{a}$ \\
\hline JKCH 1050 Bt & $218.8 \mathrm{a}$ & $47.3 \mathrm{a}$ & $1817 \mathrm{a}$ \\
\hline
\end{tabular}

${ }^{1}$ Means with the same letters within the same columns are non-significant with Fischer's Least Significant Differences (LSD) test

Early flowering was observed in hybrids JKCH 1947 BT (85 days) and JKCH $1050 \mathrm{Bt}$ (86 days) compared to the control variety Alba Plus QM 301 NBt (106 days. Damaged cotton bolls were prominent in Alba Plus QM $301 \mathrm{NBt}$ (35.6\%) compared to minimum damaged bolls in JKCH $1947 \mathrm{Bt}$ and $\mathrm{JKCH} 1050 \mathrm{Bt}$ almost (7.0\%) each (Table 1). Industrially acceptable ginning out turn percentage (GOT\%) ranged between 43.1 to $44.7 \%$ in cotton varieties except JKC $724 \mathrm{NBt}$ with $41.0 \%$. Yield indicated that out of the four varieties tested, JKCH $1947 \mathrm{Bt}(3070 \mathrm{Kg} / \mathrm{ha})$ and JKCH $1050 \mathrm{Bt}(2955$ $\mathrm{Kg} / \mathrm{ha}$ ) produced significantly superior seed cotton yield compared to control variety Alba Plus QM $301 \mathrm{NBt}(2066 \mathrm{Kg} / \mathrm{ha})$ on the first year. The same trend was observed on the second year. The lowest yielding variety was inbred JKC $724 \mathrm{NBt}(1173 \mathrm{Kg} / \mathrm{ha}$ ). Bigger boll size was observed in JKCH 1947 Bt (312 g/50 bolls) followed by JKCH 1050 Bt (295g/50bolls) and Alba Plus QM $301 \mathrm{NBt}$ (283g/50 bolls) (Table 2). Agronomic performance of Bt cultivars may vary substantially from their non-Bt counterparts (Jenkins et al., 1997).

Significantly higher number of bolls were recorded in JKCH $1050 \mathrm{Bt}$ (67.0) followed by JKCH 1947 Bt (66.0) compared to Alba Plus QM $301 \mathrm{NBt}$ (41.0). The hybrids Bt varieties JKCH $1947 \mathrm{Bt}$ and JKCH $1050 \mathrm{Bt}$ (106 days) were significantly faster in boll formation taking (102 days and 106 respectively. Alba Plus QM $301 \mathrm{NBt}$ took the longest time of 159 days. Control entry Alba Plus QM $301 \mathrm{NBt}(\%$ boll damage $2.4 \%$ ) had more boll damage compared to minimum boll damage in JKCH $1947 \mathrm{Bt}(0.5 \%)$ and $\mathrm{JKCH} 1050 \mathrm{Bt}(0.7 \%)$ (Table 3). Industrially acceptable ginning out turn (\%) was observed in JKCH $1050 \mathrm{Bt}(47.3 \%)$, JKCH $1947 \mathrm{Bt}$ (46.3\%) and control variety Alba Plus QM $301 \mathrm{NBt}$ (45.7\%). JKC 724 NBt exhibited a low GOT\% (44.0\%). Based on the weight of 50 balls per variety, Hybrid JKCH 1947 Bt (227 g/50 bolls) had bigger boll size followed by Alba Plus QM 301 NBt (220g/50 bolls) and JKCH $1050 \mathrm{Bt}$ (218 g/50 bolls). Significant differences were again observed on yield of the four 
cotton varieties trials on the second with JKCH $1050 \mathrm{Bt}(1817 \mathrm{Kg} / \mathrm{ha})$ and JKCH $1947 \mathrm{Bt}(1765 \mathrm{Kg} / \mathrm{ha})$ compared to control variety Alba Plus QM $301 \mathrm{NBt}(1337 \mathrm{Kg} / \mathrm{ha})$. The lowest yield was observed in inbred JKC 724 NBt (821 Kg/ha) (Table 4).

\section{Discussion}

Yield is dependent on many component characters, such as boll weight, number of bolls per plant and harvest index. Bt cotton hybrids produce increased seed cotton yield over their non-Bt counter parts and check hybrids, Bt cotton hybrids recorded more than $100 \%$ increased seed cotton yield over nonBt and control hybrids (Anon, 2002).

The Increased yield is attributed to the Bt-genotypes in JKCH $1947 \mathrm{Bt}$ and JKCH 1050. Bolls in the Bt hybrid varieties were protected, while only those that survived the pest pressure were harvested under the local Alba Plus QM 301NBt and the inbred JKC 724 NBt. The two Bt-genotypes eliminate shedding of bolls due to bollworm infestation. Alba Plus QM 301NBt and the inbred JKC $724 \mathrm{NBt}$ suffered from significant boll worm damage. This culminated to the higher seed cotton yield on Bt- genotypes over the local checks.

Since cotton is grown under rain fed condition, the number of days to flowering became is important to cotton producers. The earlier the cotton flowers it the earlier is the maturity time and exposure to heat unit required for crop maturity compared to late flowering varieties. This contributed to high-yielding ability, JKCH 1947Bt and JKCH 1050Bt in both years of experiment. Bt hybrids recorded significantly higher yield than the corresponding non-Bt hybrids. Early-maturity and high-yielding ability is double benefit to the rain fed farmers. The early maturity provide farmers with drought escape toward climate change. Quick trait will help the hybrids to escape from terminal moisture stress in the season. This makes the cultivar to be preferred under rain fed areas (Hofs et al., 2006).

Numbers of bolls per plant play a vital role in determining final yield of a cotton variety. This is influenced directly or indirectly by the growing conditions and its genetic ability to perform in the given environmental condition (Luqman et al., 2015. The statement by Luqman et al. 2015 clearly correspond to the observation of this study where in both years, the Bt cotton cultivars expressed a higher mean number of bolls per plant compared to the local variety and the Non Bt hybrid in both locations. The results obtained from the field trials corroborated those of a trial by Sudha et al. 2011 in Govankoppa village in India.

\section{Conclusion}

This study analyzed the yield performance of two Bt cotton varieties in Eswatini over a period of 2 years based on rain fed conditions. Cultivation of hybrid Bt cotton did not only give a significantly higher yields but also realized significantly reduced insecticidal usage, hence giving security to farmers about the cotton yield. The study conducted over two year's clearly depicted good adaptability of both Bt (JKCH1050 and 1947) cotton hybrids to Eswatini environment. The varieties were early maturing and high-yielding. Adoption of these Bt varieties can help empower Swazi cotton farmers to embrace and benefit from product of modern biotechnology. It is therefore concluded that the two Bt varieties (JKCH1050 and 1947) be released to farmers for commercial growing.

\section{Recommendation}

It is recommended that the kingdom of Eswatini commercialize the growing of Bacillus thuringiensis cotton to cotton growers.

It further recommended that further studies be conducted on the four regions of Eswatini on the performance and adaptation of this technology.

\section{References}

[1].Anonymous, 2002, Evaluation of Bt-cotton hybrids project coordinator (cotton) Final Report,

[2].2001-2002, CICR, Coimbatore, India, PP-25-42.

[3].Brookes, G. \& Barfoot, P. 2013. The global income and production effects of Genetically Modified (GM) crops 1996-2011. GM crops and Food: Biotechnology in agriculture and the food chain. Journal of Landes Bioscience. 4(1):74 -83, April. 
DOI: $10.21522 /$ TIJAR.2014.SE.19.01.Art008

ISSN: $2520-3088$

[4].Bryman, A. et. al. (2014). Social research methods. New York: McGraw Hall.

[5].Central Bank of Swaziland. 2014. Annual Report. Mbabane: Swaziland.

[6].Cotton Board of Swaziland. 2013. Annual Report. Mbabane: Apollo Printers.

[7].Cotton Board of Swaziland. 2014. Annual Report. Mbabane. Apollo Printers.

[8].Craig, W., Tepfer, M., Degrassi, G. \& Ripandelli, D. 2008. An overview of general features of risk assessments of genetically modified crops. Euphytica, 164, 853-880.

[9].Hofs, L, B. Hau, D. Marais, M. Fok. 2006. Boll Distribution Patterns in Bt And Non-Bt Cotton Cultivars: II. Study on Small-Scale Farming Systems in South Africa. •Field Crops Research, Volume 98, Issues 2-3, AugustSeptember 2006, Pages 210-215.

[10]. ISAAA, 2014. Global Status of Commercialized Biotech/GM Crops: 2013. ISAAA Brief 46-2013: Executive Summary. http://www.isaaa.org/inbrief/default.asp Date of access on 24th June, 2015.

[11]. James C. 2011. Global Status of Commercialized Biotech/GM Crops: 2011. ISAAA Brief 43. Ithaca, NY: ISAAA; http://www.isaaa.org/resources/default.asp Date of access 23 August 2015.

[12]. Kotler, P. and Keller, K. 2012. Marketing Management, $14^{\text {th }}$ ed. Upper Saddle River, New Jersey: Prentice Hall.

[13]. Luqman, M., G. M. Shah, M. A. S. Raza, N. Shahid and M. Hassan, 2015. Performance of Bt cotton varieties under Khanewal conditions. Bulg. J. Agric. Sci., 21: 105-108

[14]. Mavuso, W. 2014. Swaziland embracing GM cotton, Generic Literacy Project. Available: https://www.geneticliteracyproject.org/2014/09/22/swaziland-embracinggmcotton/ Date of accessed December 2015.

[15]. Sudha, T., R. Babu., D. P. Biradar., V. C. Patil, N. S. Hebsur, S. S. Adiver and G. Shirnalli. 2011. Studies on performance of Bt cotton genotypes under rainfed situation through farmers participatory approach. Karnataka J. Agric. Sci.,24 (5): (639-642).

[16]. Thomson C. F. 2012. Swaziland business of the year Book. Commercial guide. Mbabane: Government printers.

[17]. (www.cantool.net)

[18]. (www.cantool.net)

[19]. (www.cantool.net)

[20]. (www.cantool.net) 